\title{
The effects from the international crude oil returns to Asian frontier oil and gas company stock returns
}

\author{
Thi Ngan Nguyen ${ }^{1}{ }^{*}$, Hoang Trung Nghia ${ }^{1}$, Truong Huynh Thuy $\mathrm{Vi}^{2}$
}

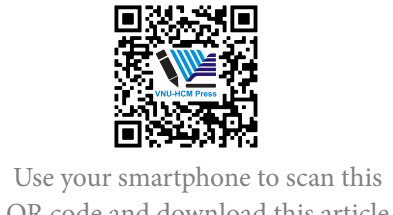

QR code and download this article

\begin{abstract}
Asian frontier markets present compelling investment opportunities for investors seeking higher returns and low correlation with traditional assets. As such, it is important for financial market participants to understand the volatility transmission mechanism across these markets in order to make better portfolio allocation decisions. This study investigates the magnitude of return and volatility spillovers from the international crude oil markets on the Asian frontier oil and gas stock markets. In particular, we construct mean return and volatility spillover models to discuss whether regional (DSE, CSE, HNX, HOSE) and global (ICE) market impacts are crucial for the determination of oil \& gas stock returns in Bangladesh, Sri Lanka, and Vietnam by employing ARMA $(1,1)-G A R C H(1,1)$ model. Using daily returns from January 4, 2010 to December 31, 2019, the findings of this paper show that the Brent oil and WTI crude oil markets influence the Sri Lanka and Vietnamese oil and gas stock markets. WTI price changes, however, have a relatively minor impact on Sri Lanka companies. For Bangladesh, it is noticeable that none of the spillover effects is statically significant. The results are explained by different levels of the reform process in the energy sector as well as by the importance of oil in these markets. In general, these frontier markets, especially the Bangladesh and Sri Lanka may offer promising diversification benefits due to low correlations with developed equity markets. These results are important for economic policymakers and investors in understanding the magnitude of volatility spillover effects of the international crude oil on these markets. Investors can use this information to make better portfolio allocation decisions to reduce risks and enhance returns. Key words: Spillover, volatility effect, crude oil futures price, oil company stock returns, Asian frontier markets
\end{abstract}

\begin{abstract}
${ }^{1}$ University of Economics and Law, Vietnam National University Ho Chi Minh City, Vietnam
\end{abstract}

${ }^{2}$ SSI Securities Corporation, Vietnam

Correspondence

Thi Ngan Nguyen, University of Economics and Law, Vietnam National University Ho Chi Minh City, Vietnam

Email: ngannt@uel.edu.vn

History

- Received: 29-12-2021

- Accepted: 13-5-2021

- Published: 18-5-2021

DOI : 10.32508/stdjelm.v5i2.749

\section{Check for updates}

Copyright

(c) VNU-HCM Press. This is an openaccess article distributed under the terms of the Creative Commons Attribution 4.0 International license.

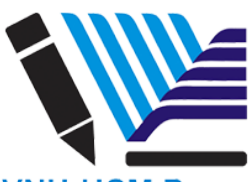

\section{INTRODUCTION}

Crude oil is arguably the most influential physical commodity in the world and plays a prominent role in an economy, thus it has become one of the major indicators of economic activities of the world. Oil price has become a fundamental factor of today's market economy as it influences financial markets as well as consumers, corporations and governments. Oil fluctuation has not only a tremendous impact over the stock markets but also a major influence on the global economy: oil is needed for industrial purpose such as power generation, chemical products, transportation etc. In particular oil demand and supply drive volatility and any upward or downward price movements is tracked by any financial market player as it directly influences future outlook and real growth of exporting and importing countries.

Over the past few years, a rising demand from developing economies and limited supplies from oil producing countries due to political tensions have frequently pushed oil prices to dramatically high levels. In 2019, the global crude oil market witnessed the perplexing movements of oil prices due to escalation in political, geopolitical tensions and unforeseen events. Oil prices constantly adjusted when worries about the health of the world's economy and increasingly uncertain trade relations due to the fact that U.S.- China trade battle would have crimped global oil demand whereas U.S. inventories and oil exports continued to increase. Then, oil prices surged by $14.3 \%$ after only 2 days (September 15 and 16, 2019), when a drone attacked upon a refinery of Saudi Aramco Group which cut off 5 percent of daily global oil supply for weeks. However, oil prices were soon corrected, as production activities fully recovered in the following weeks. Afterwards, the positive movements came from the U.S- China trade talks in late 2019. The frequent upheavals in crude oil market have entailed the shocks to the international stock market.

In view of the crucial role of oil in the global economy and its spectacular price fluctuations in recent years, it is worth concerning about the impact of the price of oil on stock prices, especially on oil-related listed companies. There are a number of previous works which have studied the interactions between oil prices and stock markets. However, very little attention is 
paid to the direct impact of the oil price shocks on stock returns of oil-related companies.

On the one hand, frontier markets are increasingly sought by investors in search of higher returns and low correlations with global markets. In particular, outsized gains in the equity markets have resulted in increased investment portfolio allocations in frontier assets. As such, it is important for financial participants to understand the volatility transmission mechanism across these markets in order to make better portfolio allocation decisions. Despite the growing attention to frontier markets among the investment community, very little research actually includes them.

Focusing on Asian frontier markets, this paper attempts to empirically examine the level of spillover effects from the international crude oil markets on oil and gas company stock returns in the three Asian Frontier Markets (Bangladesh, Sri Lanka, Vietnam), based on crude oil futures returns and the oil and gas company stock returns. For the daily returns from 2010 to 2019 of the international crude oil futures prices from the Brent markets, the WTI markets and Bangladeshi, Sri Lankan as well as Vietnamese oil \& gas stock prices are analyzed utilizing the ARMA(1,1)-GARCH(1,1). In particular, the return spillover is modeled using $\operatorname{ARMA}(1,1)$, volatility spillover is estimated using a two-step $\operatorname{GARCH}(1,1)$ model. By employing a mean and volatility spillover model that deals with the Brent oil and WTI oil stock market shocks as exogenous variables in $\operatorname{ARMA}(1,1)$, GARCH $(1,1)$ for the Asian Frontier Markets to analyze the international transmission between these markets. The empirical results in this research may be helpful for academics, domestic policy makers, and financial participants understanding the magnitude of volatility spillover effects of the international crude oil on these markets. Moreover, this study contributes to the growing literature on the spillover effects and volatility transmission of equity returns.

The rest of the paper is organized as follows. Theoretical overview and literature review on the study of return and volatility spillover across markets is presented in the next section. Section 3 gives details about research data, the descriptive statistics and financial model for estimating volatility transmissions and spillover effects and as well as estimation procedure. The empirical results are given in section 4 and finally, in the last chapter, the paper closes with concluding comments.

\section{LITERATURE REVIEW}

In recent years, the on-going liberalization of capital mobility along with advances in information technology has caused international financial markets to become highly integrated and interdependent. Consequently, the deeper the level of global financial integration, the more connected between stock markets increases, resulting in a strong spillover effect across markets. Volatility spillover between markets or assets is a tendency for volatility to change in one market or asset following a change in the volatility of another (Brooks $\left.{ }^{1}\right)$. Numerous studies have investigated the process of volatility spillover to exhibit the spread of news from one market that affects the volatility spillover process of another market.

The comprehensive influence of oil price shocks on economies is not only an important issue among various regulatory agencies, enterprise managers and market participants, but also under scrutiny by many economists. Many studies have been done on international transmission of stock returns in the context of the mean and/or volatility spillover effects. Most of them show some evidences of international transmission from major markets, such as the US and Japanese markets, toward the other developed and emerging markets.

Pan and Hsueh ${ }^{2}$ examined the nature of transmission of stock returns and volatility between the U.S. and Japanese stock markets, a two-step GARCH approach is utilized. By using futures prices on the S\&P500 and Nikkei225 stock indexes, they found that there are unidirectional contemporaneous return and volatility spillovers from the U.S. to Japan. Specifically, the U.S. influence on Japan in returns is approximately four times as large as the other way around. There are also no significant lagged spillover effects in both returns and volatility from the Japan to the U.S. while a significant lagged volatility spillover is observed from the U.S. to Japan.

Mervyn and Wadhwani ${ }^{3}$ applied correlation coefficients to stock market returns in order to examine how the market crash in the U.S. influenced the stock markets in Japan and the U.K. by using the GARCH model, co-integration tests, and the probability of specific events. The results show that the U.S. stock market crash significantly increased the correlation coefficients between multiple markets.

Expanding this issue to the context of oil and stock markets is also of great concern due to the important role of oil in the global economy. The international crude oil market is the source of the primary feedstock for creating refined petroleum products produced in 
oil refineries across the world. Crude oil has been deemed the life blood of industrial economics. Crude oil is arguably the most influential physical commodity in the world and plays a prominent role in an economy. Therefore, oil prices fluctuation clearly affects the world economy in many different ways. Rising crude oil prices raises the cost of production of goods and services, transportation and heating cost. As a result, it provokes concerns about inflation and restricted discretionary spending of consumer and produces a negative effect to financial markets, consumer confidence, and the macroeconomy (Mork ${ }^{4}$ ).

The value of stock prices in an equity pricing model theoretically equals the discounted earning expectation of companies or future cash flows. Therefore, oil price shocks influence stock prices through expected cash flow and discount rate. Since oil is one of the crucial inputs for goods and services production, a rise in oil prices without substitute inputs increases production costs; which in turns decrease cash flows and stock prices. In addition, rising oil prices affects the discount rate by influencing the inflation pressures which also leads to the decision making by the central bank to raise interest rate. Therefore, the corporate investment decision can be affected directly by change in the discount rate and change in stock price relative to book value. However, it is worth noting that not all companies will react the same way to changes in crude oil prices. Indeed, the direction of stock price reactions will depend on whether the company is an oil producer or an oil consumer. Oil producers will profit from an oil price increase while oil consumers will suffer from it. Overall, since the great majority of companies are oil consumers, it is logical to expect a negative effect of oil prices on stock prices.

From an empirical perspective, a number of previous papers have observed and provided explanation of the oil price and stock market relationship and the negative impact of oil price on stock markets. Early papers finding a negative relationship between oil prices and stock market returns include Jones and Kaul ${ }^{5}$, for Canada and the U.S., Sadorsky ${ }^{6}$ for the U.S., and Papapetrou $^{7}$ for Greece. Nandha and Faff ${ }^{8}$ report a negative connection between oil prices and global industry indices, Chen ${ }^{9}$ establishes that an increase in oil prices leads to a higher probability of a declining S\&P index. In an important contribution, Kilian and Park ${ }^{10}$ emphasize that in analyzing the influence of oil prices on the stock market, it is essential to identify the underlying source of the oil price shocks. Kilian and Park ${ }^{10}$ show that oil price increases driven by aggregate demand cause U.S. stock markets to rise and that those driven by oil-market specific demand shocks cause stock markets to fall. With regard to the effect of oil price shocks on stock market volatility, Malik and Ewing ${ }^{11}$ find evidence of significant transmission of volatility between oil and some sectors in the US stock market, Vo ${ }^{12}$ shows that there is inter-market dependence in volatility between U.S. stock and oil markets, and Arouri et al. ${ }^{13}$ report that there is volatility transmission from oil to European stock markets. Degiannakis et al. ${ }^{14}$ show that a rise in price of oil associated with increased aggregate demand significantly raises stock market volatility in Europe, and that supply-side shocks and oil specific demand shocks do not affect volatility

More specifically, as studies particularly focus on the effects of oil price changes on oil \& gas stock market. The study by Jones and Kaul ${ }^{5}$ was the first contribution to examine the reaction of stock markets to oil shocks. The authors consider four developed markets (Canada, Japan, UK and US) and draw empirical results from a standard present value model. They find that changes in stock prices can be partially accounted for by the effect of oil price movements on the current and future cash-flow.

Subsequently, Sadorsky ${ }^{6}$ and Apergis and Miller ${ }^{15}$, among others, also provided evidence of significant responses of stock returns to oil shocks from making use of various approaches such as vector autoregressive (VAR) model, international multifactor asset pricing models, cointegration, and vector errorcorrection model (VECM).

Arouri et al. ${ }^{13}$ studied on return and volatility transmission between world oil prices and stock markets of the GCC countries. This paper investigated the return links and volatility transmission between oil and stock markets in the Gulf Cooperation Council (GCC) countries over the period 2005-2010. They employed a recent generalized VAR-GARCH approach which allows for transmissions in return and volatility. In addition, they analyzed the optimal weights and hedge ratios for oil-stock portfolio holdings. On the whole, their results point to the existence of substantial return and volatility spillovers between world oil prices and GCC stock markets, and appear to be crucial for international portfolio management in the presence of oil price risk.

For frontier markets, Gomes and Chaibi ${ }^{16}$ examined volatility spillovers between oil prices and stock returns on Frontier Markets. This paper employed a bivariate BEKK-GARCH $(1,1)$ model to simultaneously estimate the mean and conditional variance between equity stock markets (twentyone national frontier stock indices and two broad indices - the MSCI Frontier Markets and the MSCI World) and oil prices. 
They examined weekly returns from February 8, 2008 to February 1, 2013 and find significant transmission of shocks and volatility between oil prices and some of the examined markets. Moreover, this spillover effect is sometimes bidirectional.

For the Vietnamese stock market, Trinh and Dan ${ }^{17}$ investigated the asymmetric impact of the oil price fluctuation on the Vietnamese stock market in the short run and long run after the financial crisis in 2008. Using non-linear autoregressive distributed lag model (ARDL) associated with the bound test to monthly data of VN-Index, crude oil Brent price, industrial production index, and money supply. The results show that in the long run, the oil price has the significant negative impact on the domestic stock market and the stock market in the short run has an opposite response with the oil price fluctuation compared with in the long run.

Surprisingly up to this period, there is a very limited amount of literature work based on the relationship between oil price and oil-related company stock price, especially in the three Asian Frontier markets. This paper, therefore, aims to extend the current literature on the relationship.

\section{METHODOLOGY}

\section{ARMA $(1,1)$ model}

The family of autoregressive integrated moving average (ARIMA) model, usually associated with Box and Jenkins is an important class of time series models. An analysis of a single time series such as financial data like a series of daily stock returns is called a univariate time series which are a class of specifications where one attempts to model and to predict financial variables using only information contained in their own past values and possibly current and past values of an error term.

Box and Jenkins ${ }^{18}$ first introduced ARIMA models, the term deriving from:

$\mathrm{AR}=$ autoregressive

$\mathrm{I}=$ integrated

$\mathrm{MA}=$ moving average.

The general ARIMA model is called an ARIMA(p, $d$, $q)$, with $p$ being the number of lags of the dependent variable (the AR terms), $d$ being the number of differences required to take in order to make the series stationary, and q being the number of lagged terms of the error term (the MA terms).

The ARMA $(1,1)$ model is the autoregressive of order one model $(\mathrm{p}=1)$, stationary time series $(\mathrm{d}=0)$, and the moving average of order one $(q=0)$, which has the form:
$\mathrm{Y}_{t}=\Phi_{o}+\Phi_{1} \mathrm{Y}_{t-1}+\Phi_{2} \varepsilon_{t-1}+\mathrm{u}_{t}$

The implication of the AR (1) is that the time series behaviour of $\mathrm{Y}_{t}$ is largely determined by its own value in the preceding period. So, what will happen in $t$ is largely dependent on what happened in $t-1$. Also, the MA (1) shows that $Y_{t}$ depends on the value of the immediate past error, which is known at time $t$.

\section{GARCH $(1,1)$ model}

Mainly financial and economic time series have a feature of volatility clustering, meaning that conditional heteroskedasticity exists. While the generalized conditional heteroskedasticity GARCH model can capture better the relevant features of financial data.

The GARCH model allows the conditional variance to be dependent upon previous own lags, so that the conditional variance equation in $\operatorname{GARCH}(1,1)$ model is given by:

$\sigma_{t}^{2}=\alpha_{0}+\alpha_{1} \mathrm{u}^{2}{ }_{t-1}+\alpha_{2} \sigma_{t-1}^{2}$

In $\operatorname{GARCH}(1,1)$ model $\sigma^{2}$ is known as the conditional variance since it is a one-period ahead estimate for the variance calculated based on any past information thought relevant. Using the GARCH model it is possible to interpret the current fitted variance as a weighted function of a long-term average value (dependent on $\alpha_{0}$ ), information about volatility during the previous period $\left(\alpha_{1} \mathrm{u}^{2}{ }_{t-1}\right)$ and the fitted variance from the model during the previous period $\left(\alpha_{2} \sigma_{t-1}^{2}\right)$.

Under GARCH, the conditional mean equation which describes how the dependent variable, $\mathrm{Y}_{t}$, varies over time, could take the form of $\operatorname{ARMA}(1,1)$. The ARMAGARCH $(1,1)$ model is given by:

$\mathrm{r}_{t}=\Phi_{o}+\Phi_{1} \mathrm{r}_{t-1}+\Phi_{2} \varepsilon_{t-1}+\varepsilon_{t}$

$\varepsilon_{t} \sim \mathrm{N}\left(0, \sigma^{2}{ }_{t}\right)$

$\sigma^{2}{ }_{t}=\alpha_{0}+\alpha_{1} \varepsilon^{2}{ }_{t-1}+\alpha_{2} \sigma_{t-1}^{2}$

The GARCH model incorporating ARMA process, on one hand, can eliminate the conditional heteroskedasticity; on the other hand, it can be used to distinguish different factors causing financial data fluctuation.

\section{The two-stage GARCH model}

The paper employs the idea of the two-stage GARCH model in Liu and Pan ${ }^{19}$ to examine the international transmissions of the mean and volatility the international crude oil returns to the three Asian frontier oil and gas company stock returns. The GARCH model allows observing the "conditional" volatility of the stock returns by accounting for volatility clustering and leptokurtosis which are properties of the data. In general, a GARCH $(1,1)$ model would be sufficient to capture the volatility gathering in the data, and rarely 
is any higher order model estimated or even entertained in the academic finance literature (Brooks ${ }^{1}$ ). The $(1,1)$ in parentheses is a standard notation in which the first number refers to how many autoregressive lags, or ARCH terms, appear in the equation, while the second number refers to how many moving average lags are specified, which is often called the number of GARCH terms. The conditional variance is a linear function of 1 lag of the squares of the error terms $\left(\varepsilon_{t}\right)$ (also referred to as the "news" from the past) and 1 lag of the past values of the conditional variances $\left(\sigma_{t}\right)$ or the GARCH terms, and a constant $\omega$. Therefore, the model used in our research is the $\operatorname{ARMA}(1,1)$ $\operatorname{GARCH}(1,1)$ and can be summarized as below.

In the first stage, Brent and WTI returns are estimated through the following $\operatorname{ARMA}(1,1)-\operatorname{GARCH}(1,1)$ model with the mean and variance equations:

$\mathrm{r}_{t, i}=\Phi_{o, i}+\Phi_{1} \mathrm{r}_{t-1, i}+\Phi_{2} \varepsilon_{t-1, i}+\varepsilon_{t, i}(1)$

$\varepsilon_{t, i} \sim \mathrm{N}\left(0, \sigma_{t, i}^{2}\right)$

$\sigma_{t, i}^{2}=\alpha_{0, i}+\alpha_{1} \varepsilon^{2}{ }_{t-1, i}+\alpha_{2} \sigma_{t-1, i}^{2}(2)$

Where $r_{t}$ is the daily stock index return; $i$ represents for Brent and WTI; and $\varepsilon_{t}$ is the residual which has standard properties with mean zero and variance $\sigma^{2}$. The model specification assumes that the ICE stock market returns are not affected by other markets, i.e., no international transmission exists. The residual $\varepsilon_{t}$ is the short-term fluctuation which expresses the unexpected events, new information or innovation in Brent and WTI returns and spreads to the twelve oil \& gas companies in the three Asian frontier markets stock returns. Consequently, the residual series is employed to capture the spillover effects from international petroleum markets to the three Asian frontier petroleum markets. The larger the residuals are, the more likely they spread.

In the second stage, on the assumption that the twelve oil \& gas companies in the three Asian Frontier Markets stock returns could be affected by information about volatility $(\varepsilon)$ of Brent crude oil return and WTI crude oil return. Hence, the international transmission from the ICE market to the three Asian frontier markets could be existed in terms of the mean and volatility effects. To capture this, we use an appropriate $\operatorname{ARMA}(1,1)-G A R C H(1,1)$ model for Banladeshi, Sri Lankan and Vietnamese oil company stock returns, where the mean and volatility equations include the residuals and residual squares obtained in the first stage GARCH model as exogenous variables. The residual is derived from equation (1) and its square from equation (2).

As shown in Table 2, the closing time for the ICE market is earlier than the three Asian frontier markets. Thus, a shock in ICE stock market during day $t$ will not be reflected in the Banladeshi, Sri Lankan and Vietnamese stock markets until day $t+1$. As a result, the appropriate pairing is time $t-1$ for the ICE stock markets and time $t$ for the Asian frontier markets.

That is, our model is given by:

$\mathrm{r}_{t, i}=\Phi_{o}+\Phi_{1} \mathrm{r}_{t-1, i}+\Phi_{2} \varepsilon_{t-1, i}+\lambda_{B R E N T} \mathrm{e}_{B R E N T, t-1}$

$+\lambda_{W T I} \mathrm{e}_{W T I, t-1}+\varepsilon_{t, i}$

$\varepsilon_{t, i} \sim \mathrm{N}\left(0, \sigma^{2}{ }_{t, i}\right)$

$\sigma_{t, i}^{2}=\alpha_{0}+\alpha_{1} \varepsilon^{2}{ }_{t-1, i}+\alpha_{2} \sigma_{t-1, i}^{2}+$ $\gamma_{B R E N T} \mathrm{e}^{2}{ }_{B R E N T, t-1}+\gamma_{W T I} \mathrm{e}^{2}{ }_{W T I, t-1}$

Where $\mathrm{e}_{W T I, t-1} \quad\left(\mathrm{e}_{\text {BRENT,t-1 }}\right)$ and $\mathrm{e}^{2}$ WTI,t-1 $\left(\mathrm{e}^{2}\right.$ BRENT,t-1) are the residual and the square of the residual for the Brent crude oil return and WTI crude oil return collected from equations (1) and (2). The coefficients $\lambda_{B R E N T}$ and $\lambda_{W T I}$ capture the mean spillover effect and the coefficients $\gamma_{L C O C 1}$ and $\gamma_{D J U S E N}$ capture the volatility spillover effect from the Brent crude oil return and WTI crude oil return. On the other hand, a statistically significant value for $\Phi_{1}, \alpha_{2}$ suggest the dependence on own-mean and own-volatility previous values.

\section{DATA}

Data employed in the thesis are daily adjusted closing for Brent crude futures prices (LCOc1), WTI crude futures prices (WTCLc1) and the twelve oil and gas companies in three Asian frontier markets namely Bangladesh, Sri Lanka and Vietnam over the sample period from January 4, 2010 to December 31, 2019. It is worth noting that in Bangladesh and Sri Lanka, oil and gas industry is managed largely by state-owned corporations. To improve efficiency and develop this sector, government has gradually been showing efforts to restructure by privatising state enterprises as well as loosening restrictions of regulation framework. However, this transformation is running slow so that the number of publicly held companies is relatively small. As listed below, these are all oil and gas companies available on Bangladeshi and Sri Lankan stock markets.

The data are retrieved from Thomson Reuters and expressed in local currencies with the only exception of Brent and WTI crude oil futures prices, which are denominated in USD per barrel. It is important to use high frequency data for any series modeled by GARCH. As a result, daily data would be ideal to capture most of the possible interactions.

For global crude oil price, this paper uses Brent and WTI crude oil futures prices which are instruments of the two most popular grades of Crude Oil benchmarks. Brent and WTI contracts are traded through ICE Futures Europe, ICE's London-based, futures exchange for the global energy markets. All ICE energy 
products are cleared at ICE Clear Europe, ICE's London based clearing house, which clears an average of more than 3 million energy contracts every day.

For the Bangladesh market, the five Oil \& Gas companies traded on Dhaka stock exchange are used. They are JAMUNAOIL (Jamuna Oil Company Limited), EMERALDOIL (Emerald Oil Industries Ltd.), PADMAOIL (Padma Oil Co. Ltd.), TITASGAS (Titas Gas Transmission \& Dist. Co. Ltd.) and MPETROLEUM (Meghna Petroleum Limited). Four of them (except for Mpetroleum) are the top fuel compaines with maximum market capitalisation, market liquidity and fundamental stability at Bangladeshi stock exchange. Regarding Sri Lanka's market, the two Oil \& Gas companies traded on Colombo stock exchange are chosen namely LAUGFS GAS PLC (LGL) and LANKA IOC PLC (LIOC). For the Vietnamese market, the five oil \& gas company stock prices traded on Ho Chi Minh Stock Exchange (HOSE) and Ha Noi Stock Exchange (HNX) are used. They are major enterprises with large market capitalization and cover all three types of activities known as the upstream, midstream, and downstream in the Vietnam's oil and gas industry. They are composed of PetroVietnam Gas Joint Stock Corporation (GAS, HOSE), Viet Nam National Petroleum Group (PLX, HOSE), PetroVietnam Technical Services Corporation (PVS, HNX), PetroVietnam Drilling \& Well Services Corporation (PVD, HOSE), Petrovietnam Fertilizer \& Chemicals Corporation (DPM, HOSE). Upstream group includes PVS and PVD. They are enterprises invested with large capital and considerably affected by international oil price fluctuation. GAS belongs to midstream and plays transporting and distributing roles, whereas PLX and DPM represent downstream group. The more upstream the enterprise, the greater the effect of oil price on its operating income.

The number of observations is approximately 5160 for crude oil market, 4586 for Sri Lanka, 8320 for Bangladesh and 9876 for Vietnam. The paper analyzes the exogenous effects of Brent and WTI returns and volatilities on the twelve oil company stock returns and volatilities.

The stock indices and their home countries are presented in Table 1. Also presented are their trading hours in both local and UTC time for the purpose of studying the same effects. Each stock market operates in different time zones with different opening and closing times, so that the daily rates of return represent the returns in different real time periods. As can be seen from the table (Trading-UTC column), the ICE market closes later than the Asian frontier markets; therefore, a shock in this market during day t will not be reflected in the Asian frontier stock markets until day $t+1$. Thus, the appropriate pairing is time $t-$ 1 for Brent and WTI returns and time $t$ for the twelve oil and gas company stock returns.

The unit of measurement for each market is transformed to a daily rate of return as below, which is defined as the natural logarithmic returns in two consecutive trading days:

$\mathrm{r}_{t}=\ln \left(\mathrm{p}_{t}\right)-\ln \left(\mathrm{p}_{t-1}\right)=\ln \left(\mathrm{p}_{t} / \mathrm{p}_{t-1}\right)$

Where $\mathrm{r}_{t}$ is the daily log return, $\mathrm{p}_{t}$ and $\mathrm{p}_{t-1}$ are the daily adjusted closing prices at time $t$ and $t-1$.

The plots for the daily log returns fluctuate around a zero mean (see Figure 1). Each of all series appears to show the signs of ARCH effects in that the amplitude of the returns varies over time. These financial data also exhibit "volatility clustering" or "volatility pooling". Volatility clustering describes the tendency of large changes in asset prices (of either sign) to follow large changes and small changes (of either sign) to follow small changes. In other words, the current level of volatility tends to be positively correlated with its level during the immediately preceding periods. This phenomenon is demonstrated in Figure 1. As reflected from the time series data set of oil returns, all of the variables show significant volatility clustering with a lot of abnormal spikes during 2010-2019, indicating that the GARCH class model should also be used to describe their volatility process.

Table 2 and Table 3 present a wide range of descriptive statistics for the daily stock returns of Bent crude oil futures, WTI crude oil futures and the twelve oil stock prices from January 2010 to December 2019.

According to Table 2 and Table 3, out of twelve company stock returns, seven display negative daily returns, more specifically, four out of five companies in Bangladesh, half of companies in Sri Lanka and two out of five companies in Vietnam. While for Brent and WTI returns, the mean returns are negative at $-0,00007$ and $-0,00011$, respectively. The highest daily mean return is posted by GAS in Vietnam $(0,00065)$, while the lowest average daily return comes from TITAS in Sri Lanka $(-0,00037)$. The volatility represented by standard deviation of Brent crude oil returns WTI crude oil returns are lower than almost all oil companies. EMOI in Bangladesh has the highest standard deviation (0.038720), whereas Brent has lowest $(0,01903)$. The high degrees of kurtosis reveal a fat-tailed distribution of both returns and the skewness coefficient is different from zero, indicating the rejection of the normality condition for the data series.

Strong evidence of autocorrelations and conditional heteroskedasticity for both markets is provided by 
Table 1: Indices, home countries, time-zones and trading hours in local and UTC time

\begin{tabular}{|c|c|c|c|c|c|c|}
\hline \multirow[t]{2}{*}{ Index } & \multirow[t]{2}{*}{ Country } & \multirow{2}{*}{$\begin{array}{l}\text { Time- } \\
\text { Zone }\end{array}$} & \multicolumn{2}{|c|}{ Trading - local time } & \multicolumn{2}{|c|}{ Trading - UTC } \\
\hline & & & Open & Close & Open & Close \\
\hline BRENT & The U.K. & UTC & $1: 00$ & 23:00 & 1:00 & 23:00 \\
\hline WTI & The U.K. & UTC & 1:00 & 23:00 & 1:00 & 23:00 \\
\hline $\begin{array}{l}\text { Bangladesh oil and gas stock } \\
\text { prices }\end{array}$ & Bangladesh & $\mathrm{UTC}+6$ & $10: 30$ & $14: 30$ & 04:30 & $08: 30$ \\
\hline Sri Lanka oil and gas stock prices & Sri Lanka & $\mathrm{UTC}+5,5$ & 09:30 & $14: 30$ & 04:00 & 09:00 \\
\hline $\begin{array}{l}\text { Vietnamese oil and gas stock } \\
\text { prices }\end{array}$ & Vietnam & $\mathrm{UTC}+7$ & 9:00 & $15: 00$ & 2:00 & 8:00 \\
\hline
\end{tabular}

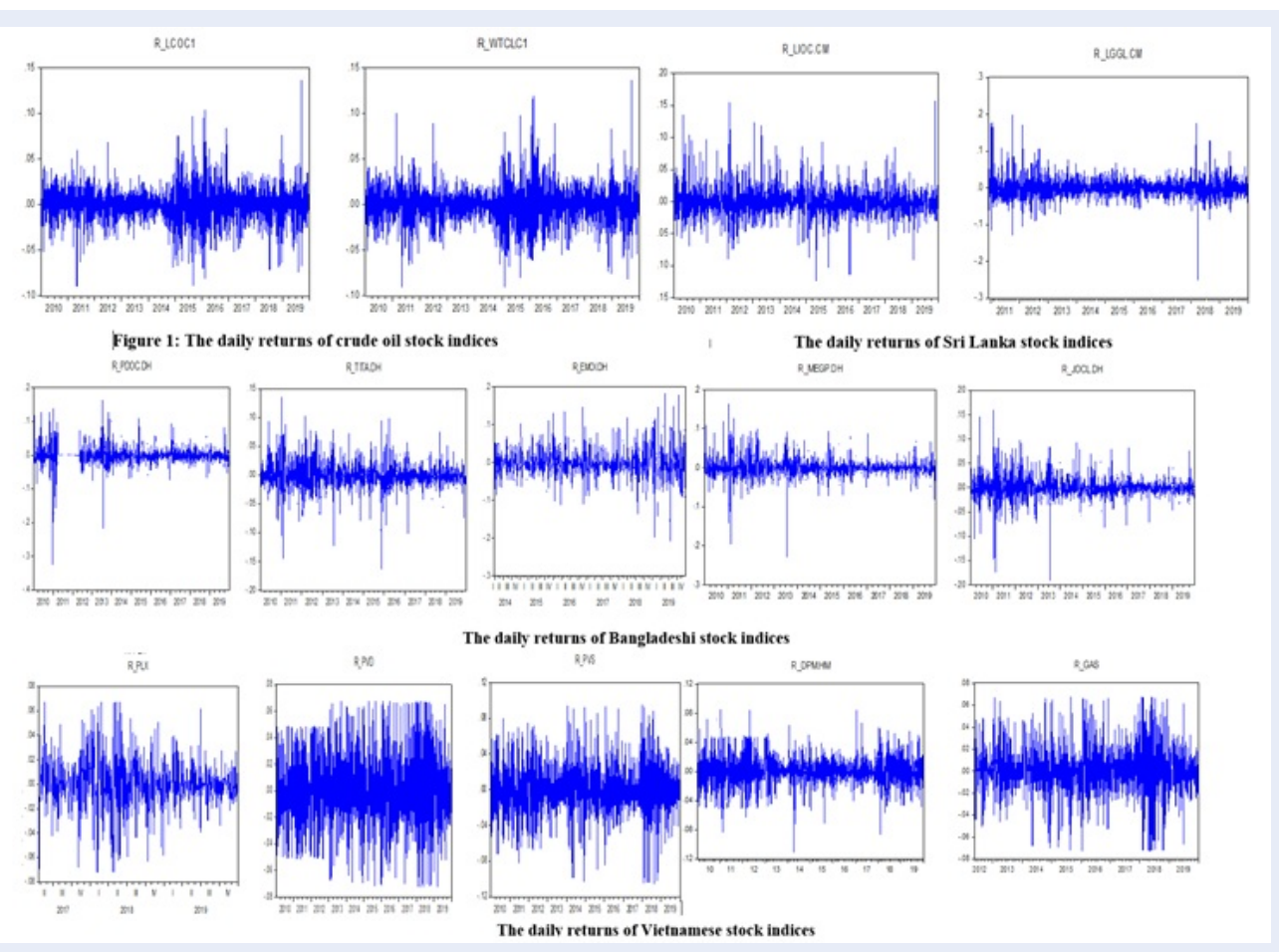

Figure 1: The daily returns of indices

the Ljung-Box (LB) statistic for lags 12 and 24 for returns as well as squared returns. The Ljung-Box (LB) Q statistics for daily stock returns of several assets namely MEGP, JOCL, PDOC, TITA in the Bangladeshi stock market are highly significant at five-percent level suggesting that the residuals are serially correlated. Furthermore, the presence of highly significant autocorrelations in the squared series indicates the time-varying volatility.

The significant autocorrelation among squared returns and excess kurtosis are compatible with the volatility clustering phenomenon that lead to con- sider the (Generalized Autoregressive Conditional Heteroskedasticity) GARCH type models that can accommodate time-varying and persistent behavior of volatility of returns. Besides, the p-value of Arch Test shown in the last row are all zero to both places, resoundingly rejecting the "no ARCH" hypothesis.

Furthermore, the presence of serial correlations and time-varying volatility make the traditional OLS regression inefficient. These features of the data lead us to consider the GARCH type models that can accommodate time-varying and persistent behavior of volatility of returns. We start modeling with 
Table 2: Descriptive statistics for daily stock returns of the oil and the Vietnamese markets

\begin{tabular}{llllllll}
\hline & BRENT & WTI & GAS & DPM & PLX & PVS & PVD \\
Mean & $-0,00007$ & $-0,00011$ & 0,00065 & $-0,00002$ & 0,0004 & 0,00017 & $-0,00035$ \\
Max & 0,13639 & 0,13694 & 0,0675 & 0,08483 & 0,0675 & 0,0953 & 0,0677 \\
Min & $-0,08963$ & $-0,0907$ & $-0,0725$ & $-0,11093$ & $-0,0723$ & $-0,015$ & $-0,073$ \\
Std,dev & 0,01903 & 0,02049 & 0,0214 & 0,01825 & 0,022 & 0,025 & 0,024 \\
Skewness & 0,10734 & 0,19909 & $-0,0486$ & 0,02177 & $-0,056$ & $-0,1067$ & 0,042 \\
Kurtosis & 6,67998 & 6,48738 & 4,9914 & 5,69237 & 4,787 & 5,324 & 3,758 \\
LB(12) & 15,409 & 10,609 & 19 & 19,222 & 7 & 8 & 19 \\
& 0,118 & 0,389 & 0,08 & 0,038 & 0,8 & 0,7 & 0,06 \\
LB(24) & 23,466 & 24,455 & 38 & 35,341 & 17 & 19 & 38 \\
& 0,376 & 0,32 & 0,02 & 0,036 & 0,8 & 0,7 & 0,03 \\
LB2(12) & 520,99 & 512,5 & 835 & 334,54 & 279 & 568 & 445 \\
& 0,0 & 0,0 & 0,0 & 0,0 & 0,0 & 0,0 & 0,0 \\
LB2(24) & 756,12 & 794,96 & 1007 & 450,25 & 395 & 686 & 527 \\
& 0,0 & 0,0 & 0,0 & 0,0 & 0,0 & 0,0 & 0,0 \\
ARCH & 235,47 & 225,433 & 318 & 403 & 116 & 181,47 & 203 \\
\hline
\end{tabular}

Notes: GAS is PetroVietnam Gas Joint Stock Corporation DPM is Petrovietnam Fertilizer \& Chemicals Corporation PLX is Viet Nam National Petroleum Group PVS is PetroVietnam Technical Services Corporation PVD is PetroVietnam Technical Services Corporation

$\operatorname{ARMA}(1,1)-G A R C H(1,1)$.

\section{EMPIRICAL RESULTS AND DISCUSSION}

Empirical models for the twelve oil \& gas companies in the three Asian frontier stock returns are given below:

$\mathrm{r}_{t, i}=\Phi_{o}+\Phi_{1} \mathrm{r}_{t-1, i}+\Phi_{2} \varepsilon_{t-1, i}+\lambda_{B R E N T} \mathrm{e}_{B R E N T, t-1}$

$+\lambda_{W T I} \mathrm{e}_{W T I, t-1}+\varepsilon_{t, i}$

$\varepsilon_{t, i} \sim \mathrm{N}\left(0, \sigma^{2}{ }_{t, i}\right)$

$\sigma_{t, i}^{2}=\alpha_{0}+\alpha_{1} \varepsilon_{t-1, i}^{2}+\alpha_{2} \sigma_{t-1, i}^{2}+$ $\gamma_{B R E N T} \mathrm{e}^{2}{ }_{B R E N T, t-1}+\gamma_{W T I} \mathrm{e}^{2}{ }_{W T I, t-1}$

Tables 4,5 and 6 show the estimation results of twostage ARMA-GARCH model for the twelve pairs of oil- stock market returns in the three Asian frontier markets; Sri Lanka, Bangladesh and Vietnam, together with statistical tests applied to standardized residuals.

The results for the conditional mean equations show none of the autoregressive terms denoted by $\Phi_{1}$ coefficients in the return-generating process for stock markets is insignificant except for the four oil and gas company stock returns in Sri Lanka and Vietnam
(PLX, DPM, LIOC, LGGL). Coefficients $\Phi_{1}$ of DPM and LGGL are positive and significant at $1 \%$, suggesting that these stock returns today are affected by stock returns of the previous day. The negative and significant coefficients for the others indicate that there is no impact of return on the previous day on the today return. Current returns on the international oil futures market are also insignificantly affected by their past values. Likewise, coefficients $\Phi_{2}$ are found not to have significant explanatory power on their current values except for PLX and WTI returns. This shows that current values do not depend on the value of the immediate past error.

Taking a close look at mean equations of Brent and WTI futures price returns, as can be seen, current Brent crude oil return is not affected by its own onelagged return as well as short-term fluctuation which expresses the unexpected events, new information in the preceding day. It can be obviously explained that the price of crude oil is traditionally determined by supply and demand for itself. Moreover, as a derivative market which is based on underlying asset, oil futures market prices also rely on a continuous flow of 


\begin{tabular}{llllllll}
\hline \multicolumn{7}{l}{ Table 3: Descriptive statistics for daily stock returns of the Bangladeshi and the Sri Lanka markets } \\
\hline & LIOC & LGGL & MEGP & JOCL & PDOC & TITA & EMOI \\
Mean & 0,00006 & $-0,00019$ & 0,00027 & $-0,00015$ & $-0,00004$ & $-0,00037$ & $-0,0011$ \\
Max & 0,15751 & 0,19845 & 0,16413 & 0,15952 & 0,16356 & 0,1366 & 0,18232 \\
Min & $-0,12282$ & $-0,25172$ & $-0,22816$ & $-0,19047$ & $-0,32406$ & $-0,16343$ & $-0,20972$ \\
Std,dev & 0,02205 & 0,02718 & 0,02331 & 0,02297 & 0,025064 & 0,021854 & 0,038720 \\
Skewness & 0,78881 & 0,79982 & $-0,06119$ & $-0,16342$ & $-1,065930$ & $-0,097159$ & 0,293496 \\
Kurtosis & 9,21128 & 13,48646 & 16,01569 & 13,51456 & 30,07906 & 10,06254 & 6,618004 \\
LB(12) & 9,6149 & 12,403 & 25,116 & 18,095 & 20,045 & 19,155 & 10,176 \\
& 0,475 & 0,155 & 0,005 & 0,053 & 0,029 & 0,038 & 0,425 \\
LB(24) & 18,983 & 21 & 44,044 & 40,137 & 64,905 & 36,739 & 27,848 \\
& 0,646 & 0,521 & 0,002 & 0,01 & 0,00 & 0,025 & 0,181 \\
LB2(12) & 66,7998 & 291,21 & 214,57 & 335,24 & 256,45 & 278,65 & 160,2 \\
& 0,0 & 0,0 & 0,0 & 0,0 & 0,0 & 0,0 & 0,0 \\
LB2(24) & 795 & 366,08 & 352,64 & 530,18 & 371,18 & 387,05 & 201,23 \\
& 0,0 & 0,0 & 0,0 & 0,0 & 0,0 & 0,0 & 0,0 \\
ARCH & 235 & 302 & 133,68 & 189,54 & 169,13 & 174,29 & 83,39 \\
\hline & 0,0 & 0,0 & 0,0 & 0,0 & 0,0 & 0,0 & 0,0 \\
\hline
\end{tabular}

Notes: LIOC is LANKA IOC PLC based in Sri Lanka

LGGL is LAUGFS GAS PLC based in Sri Lanka

MEGP is Meghna Petroleum Limited based in Bangladesh

JOCL is Jamuna Oil Company Limited based in Bangladesh

PDOC is Padma Oil Company Limited based in Bangladesh

TITA is Titas Gas Transmission \& Distribution Company Limited based in Bangladesh

EMOI is Emerald Oil Industries Ltd. based in Bangladesh

information impacting the supply and demand of this asset. The information such as political, geopolitical tensions and unforeseen events in the oil-producing countries is absorbed and reflected in futures prices quickly. Therefore, this characteristic may cause wild fluctuations in crude oil returns. Last but not least, speculation of investors in their expectation of oil market partly determines crude oil futures prices. However, these factors cannot be so easily explained and require further study for explanation. Likewise, current WTI return is not affected by its own onelagged return but affected by short-term fluctuation in the day before compared to Brent return. The reason here appears because of more commonly referenced Brent price benchmark which means the more crude oil storage Brent has, the less dependence on the past shocks Brent does than WTI.

As for the estimates of ARCH and GARCH coefficients, which capture shock dependence and volatility persistence in the conditional variance equations are highly significant for all oil and stock return series at the $1 \%$ level.
Table 4 shows the results of the estimation for Bangladesh, it is noticeable that none of the spillover effects is statically significant. This indicates that Bangladesh market behaves independently from the international oil markets. However, the LB Qstatistics test shows the model does not fit well.

Regarding the results of the estimation for Sri Lanka showed in Table 5, the LB Q-statistics confirms that the model fits the data well since there is no serial correlation in the residual series. It is clear that no evidence of mean spillover is observed from the international oil markets to oil and gas stock market in Sri Lanka since the coefficients $\lambda_{W T I}$ and $\lambda_{B R E N T}$ are insignificant. This seems to suggest that a shock originating from the oil markets generally has no impact on stock market returns in the Sri Lankan market. In terms of the volatility spillover, there is only a positive significant volatility spillover effects between WTI oil market and the Sri Lankan oil and gas stock market. It means that the conditional variances of the two oil and gas companies in Sri Lanka are affected by innovations of WTI crude oil returns. The effect however 
is weak and significant only at $10 \%$ for LIOC. While the impact from Brent oil returns is absent.

Table 6 represents the estimation results for the Vietnamese market, these results are opposite to those for the Sri Lanka stock market due to the emergence of mean spillover from the conditional mean equations and the absence of volatility spillover from the conditional volatility equations of the five Vietnamese oil and gas company stock returns. Regarding the extent of mean transmission between oil and stock markets, the results show that returns on the Brent $\left(\lambda_{\text {Brent }}\right)$ significantly affect stock market returns in four out of five companies (GAS, PLX, PVS, PVD), while returns on the WTI $\left(\lambda_{W T I}\right)$ are significant in three out of five (GAS, PVS, PVD), indicating that a high return in the two those markets are followed by high returns in several Vietnamese oil and gas companies. The magnitude of the mean spillover effects from the international crude oil returns to these influenced companies is as expected that the closer upstream the enterprise, the more it is affected. On the other hand, oil's shocks, represented by $\gamma_{B r e n t}$ and $\gamma_{W T I}$ from the conditional volatility equations have no significant effects on the stock market. This finding suggests that there are no cross-volatility spillover effects between oil and the Vietnamese market. As noticeable, portmanteau LB statistics evaluate the serial correlations in the raw and squared standardized residuals of the model up to lags 5 and 9 and find that most of the conditional dependence in the return has been modeled reasonably well.

In general, the volatility of the Asian frontier markets is mainly explained by their own volatility rather than oil's. As can be observed, the estimates of ARCH and GARCH parameters are all highly significant and the sum of these two coefficients is close to unity, especially the two markets in Sri Lanka and Vietnam. Specifically, the estimated conditional volatility series do not change very rapidly under the fluctuation of return innovations given the small size of ARCH coefficients. They tend instead to evolve gradually over time with respect to substantial effects of past volatility as indicated by the large values of GARCH coefficients. Taking these results into account might help investors to better forecast future stock volatility as well as diversify their portfolio investment.

It seems that there are two main reasons for difference in spillover effects of the international crude oil markets between the Asian frontier markets. Firstly, the difference is based on the level of privatization and the extent of government interference (supporting price) in the energy sector of each market. In many developing countries, particularly in Asia, energy sector reform starts from a market structure that is dominated by a state-owned national energy utility with a legally endowed monopoly and an integrated supply chain. The rationale for this structure partly appears to minimize the impact of international market shocks. Because of the inefficiency of this structure, many developing countries have embarked on energy sector reforms by privatizing several state entities. In general, this restructure have been implemented in an attempt to ensure increased efficiency, transparency, autonomy, accountability, competition, and financial viability. However, each country has been experienced a different degree of transformation. Therefore, the higher the level of privatization, the less the extent of government interference, the more the price fluctuation of listed companies. The other reason is role of crude oil in a country. Almost all Asian countries are importers of crude oil and petroleum products. Therefore, it is clear that demand for oil in the Asian frontier countries contributes to the level of dependence on the global oil market.

In Bangladesh, none of the spillover effects from Brent or WTI market is statically significant. This can be explained due to the low level of privatization in the energy sector which is dominated by state-owned companies, as well as negligible role of oil in Bangladesh. In other words, there are only five oil and gas public companies in the Dhaka Stock Exchange and domestic coal and natural gas are primary energy supply sources.

In like manner, the evidence of volatility spillover is observed from the WTI oil market to oil and gas stock market in Sri Lanka, but the effect is weak and small. This is perhaps due to the slow transformation of the energy sector reform and the relatively high country's petroleum requirement in this country. In particular, there are only two oil and gas listed companies and Sri Lanka's oil import bill accounts for an estimated 27\% of total imports.

The magnitude of the spillover effects from the international crude oil returns to the Vietnamese market is the largest among the Asian frontier countries. Possible reasons are that this market has the highest degree of privatization in oil and gas industry as well as demand for crude oil and petroleum products.

\section{CONCLUSION}

This paper has investigated the transmission of mean return and volatility from the international crude oil returns to the three Asian frontier oil and gas company stock returns, using daily data from January 2010 to December 2019. These developing countries have increased their economic integration in recent 


\begin{tabular}{|c|c|c|c|c|c|}
\hline & MEGP & JOCL & PDOC & TITA & EMOI \\
\hline \multicolumn{6}{|c|}{ Conditional Mean Estimates } \\
\hline$\Phi_{0}$ & $-0,00032$ & $-0,00018$ & 0,00002 & $0,00109^{*}$ & $-0,00078$ \\
\hline$\Phi_{1}$ & 0,01548 & 0,00816 & 0,016855 & $-0,43742$ & $-0,027$ \\
\hline$\Phi_{2}$ & 0,01558 & 0,008133 & 0,016844 & 0,48336 & $-0,029$ \\
\hline$\lambda_{B R E N T}$ & $-0,01285$ & $-0,03299$ & 0,068273 & $-0,18104$ & 0,061 \\
\hline$\lambda_{W T I}$ & 0,04679 & 0,04849 & $-0,07260$ & 0,16128 & 0,039 \\
\hline \multicolumn{6}{|c|}{ Conditional Variance Estimates } \\
\hline$\alpha_{0}$ & $0,00049^{* * *}$ & $0,00047^{* * *}$ & $0,00058^{* * *}$ & $0,00029^{* * *}$ & $0,00010^{* * *}$ \\
\hline$\alpha_{1}$ & $0,13105^{* * *}$ & $0,13900^{* * *}$ & $0,14220^{* * *}$ & $0,09381^{* * *}$ & $0,16921^{\star * *}$ \\
\hline$\alpha_{2}$ & $0,57251^{* * *}$ & $0,56884^{* * *}$ & $0,58396^{* * *}$ & $0,33882^{* * *}$ & $0,76525^{* * *}$ \\
\hline$\gamma_{B R E N T}$ & $-0,03261$ & $-0,03127$ & $-0,04091$ & $-0,02311$ & 0,05471 \\
\hline$\gamma_{W T I}$ & $-0,03087$ & $-0,03052$ & $-0,04038$ & $-0,00055$ & $-0,02872$ \\
\hline \multicolumn{6}{|c|}{ LB Q-statistics } \\
\hline $\mathrm{LB}(5)$ & $10,249^{* *}$ & 0,8713 & 5,4435 & $10,021^{\star *}$ & 1,8988 \\
\hline $\mathrm{LB}(9)$ & 11,617 & 5,1 & 7,7393 & $11,953^{*}$ & 5,338 \\
\hline LB2(5) & $76,551^{* *}$ & $79,637^{* * *}$ & $18,538^{* * *}$ & $75,027^{\star * *}$ & 2,4867 \\
\hline LB2(9) & $107,18^{* * *}$ & $150,78^{\star * *}$ & $36,915^{\star * *}$ & $127,69^{* * *}$ & 4,1742 \\
\hline
\end{tabular}

Parentheses include the p-value, ${ }^{*}{ }^{* *}$ and ${ }^{* * *}$ indicate significance at 10,5 and $1 \%$ levels, respectively.

years, and their stock markets have achieved remarkable development. By adopting a two- stage GARCH model based on the concept of Liu and $\operatorname{Pan}^{19}$, we construct mean return and volatility spillover models to discuss whether regional (DSE, CSE, HNX, HOSE) and global (ICE) market impacts are crucial for the determination of oil \& gas stock returns in Bangladesh, Sri Lanka and Vietnam. The findings of this paper show that, the Brent oil and WTI crude oil markets influence the Sri Lanka and Vietnamese oil and gas stock market. The results also support significant feedback relationships in mean return between Brent, WTI crude oil stock returns and companies in the Vietnamese. Meanwhile, WTI price changes have an influence on volatility of Sri Lanka companies however it is weak and has small magnitude. For Bangladesh, it is noticeable that none of the spillover effects is statically significant. This indicates that Bangladesh market behaves independently from the international oil markets. The results are explained by different levels of reform process in energy sector as well as the importance of oil in these markets. In general, these frontier markets, especially the Bangladesh and Sri Lanka may offer promising diver- sification benefits due to low correlations with developed equity markets.

These results are important for economic policy makers in order to safeguard the energy sector from international oil shocks. The investors can use this information for making better portfolio allocation decisions to reduce risks and enhance returns. It also may be helpful for academics, domestic policy makers, and financial participants understanding the magnitude of volatility spillover effects of the international crude oil on these markets. Moreover, this study contributes to the growing literature on the spillover effects and volatility transmission of equity returns.

However, recent trends of international capital integration, including the existence of multinational financial institutions, could intensify the other way. Thus, careful examination on such mutual interdependence among capital markets must be needed in future research. Further research is necessary for investigating the mean and volatility transmission through multivariate GARCH (M-GARCH) models. The ability of capturing cross-market spillovers increases with MGARCH specification because of its advantages. 


\begin{tabular}{|c|c|c|c|c|}
\hline & BRENT & WTI & LIOC & LGGL \\
\hline \multicolumn{5}{|c|}{ Conditional Mean Estimates } \\
\hline$\Phi_{0}$ & 0,00019 & 0,00015 & $-0,00043$ & $-0,00052$ \\
\hline$\Phi_{1}$ & $-0,04421$ & $-0,69891^{* * *}$ & $-0,32734^{*}$ & $0,32427^{* * *}$ \\
\hline$\Phi_{2}$ & $-0,00358$ & $0,65491^{* * *}$ & 0,22221 & $-0,45439^{* *}$ \\
\hline$\lambda$ BRENT & & & 0,02218 & 0,05499 \\
\hline$\lambda \mathrm{WTI}$ & & & $-0,03071$ & $-0,05299$ \\
\hline \multicolumn{5}{|c|}{ Conditional Variance Estimates } \\
\hline$\alpha_{0}$ & $0,00000^{* * *}$ & $0,00000^{* * *}$ & $0,00011^{* * *}$ & $0,00006^{* * *}$ \\
\hline$\alpha_{1}$ & $0,06165^{* * *}$ & $0,06520^{* * *}$ & $0,14652^{* * *}$ & $0,14652^{* * *}$ \\
\hline$\alpha_{2}$ & $0,93193^{* * *}$ & $0,92588^{* * *}$ & $0,63780^{* * *}$ & $0,76037^{* * *}$ \\
\hline$\gamma$ BRENT & & & $-0,04205^{* * *}$ & $-0,06937^{* * *}$ \\
\hline$\gamma \mathrm{WTI}$ & & & $0,02831^{*}$ & $0,05428^{* * *}$ \\
\hline \multicolumn{5}{|c|}{ LB Q-statistics } \\
\hline LB(5) & 4,8766 & 1,9834 & 3,0224 & 6,6328 \\
\hline $\mathrm{LB}(9)$ & 9,2327 & 3,327 & 8,1805 & 13,232 \\
\hline LB2(5) & 5,5829 & 5,6104 & 1,1898 & 0,5509 \\
\hline LB2(9) & 7,1387 & 8,5478 & 2,6783 & 0,9057 \\
\hline
\end{tabular}

Parentheses include the p-value, ${ }^{*}{ }^{* *}$ and ${ }^{* * *}$ indicate significance at 10,5 and $1 \%$ levels, respectively.

This research is funded by Vietnam National University HoChiMinh City (VNU-HCM) under grant number C2019-34-09

\section{ABBREVIATIONS}

ARCH: Autoregressive Conditionally Heteroscedastic ARMA: Autoregressive-Moving-Average

GARCH: Generalized Autoregressive Conditionally Heteroscedastic

LB: Ljung-Box

\section{COMPETING INTERESTS}

The authors declare that they have no conflicts of interest.

\section{AUTHORS' CONTRIBUTIONS}

The research is conducted by Nguyen Thi Ngan, Hoang Trung Nghia and Truong Huynh Thuy Vi, in which Nguyen Thi Ngan and Hoang Trung Nghia are mainly responsible for this research. Nguyen Thi Ngan and Hoang Trung Nghia are responsible for conceiving and designing the analysis, contributing data and analysis tools, performing the analysis and writing the paper. Truong Huynh Thuy Vi is responsible for collecting data; interpreting data and writing the paper.

\section{REFERENCES}

1. Brooks C. Introductory econometrics for finance. Cambridge University Press, UK. 2014;Available from: https://doi.org/10. 1017/CBO9781139540872.

2. Pan MS, Paul H. Transmission of Stock Returns and Volatility between the U.S. and Japan: Evidence from the Stock Index Futures Markets. Asia-Pacific Financial Markets. 1998;5(3):211-225.

3. Mervyn. A King and Sushil Wadhwani. Transmission of Volatility between Stock Markets, Review of Financial Studies. 1990;3(1):5-33. Available from: https://doi.org/10.1093/rfs/3. 1.5.

4. Mork KA. Business Cycles and the Oil Market. The Energy Journal, Special Issue. 1994;15:15-38. Available from: https: //doi.org/10.5547/ISSN0195-6574-EJ-Vol15-NoSI-3.

5. Jones CM, Kaul G. Oil and the stock markets. The Journal of Finance. 1996;51:463-491. Available from: https://doi.org/10. 1111/j.1540-6261.1996.tb02691.x.

6. Sadorsky P. Oil price shocks and stock market activity. Energy Economics. 1999;21:449-469. Available from: https://doi.org/ 10.1016/S0140-9883(99)00020- 1.

7. Papapetrou E. Oil price shocks, stock market, economic activity and employment in Greece. 2001;23(5):511-532. Available from: https://doi.org/10.1016/S0140-9883(01)00078-0.

8. Nandha M, Faff R. Does oil move equity prices? A global view. Energy Economics. 2008;30(3):986-997. Available from: https: //doi.org/10.1016/j.eneco.2007.09.003.

9. Chen SS. Do higher oil prices push the stock market into bear territory? Energy Economics. 2010;32(2):490-495. Available from: https://doi.org/10.1016/j.eneco.2009.08.018. 
Table 6: Empirical results for Stock Returns in Vietnam

\begin{tabular}{|c|c|c|c|c|c|}
\hline & GAS & PLX & DPM & PVS & PVD \\
\hline \multicolumn{6}{|c|}{ Conditional Mean Estimates } \\
\hline$\Phi_{0}$ & $0,00075^{*}$ & 0,00000 & 0,00008 & $-0,00005$ & $-0,00025$ \\
\hline$\Phi_{1}$ & $-0,26312$ & $-0,98064^{* *}$ & $0,90778^{* * *}$ & 0,05258 & $-0,11198$ \\
\hline$\Phi_{2}$ & 0,28544 & $0,99438^{* *}$ & $-0,92512^{* * *}$ & $-0,09296$ & 0,14670 \\
\hline$\lambda_{B R E N T}$ & $0,11816^{* *}$ & $0,23421^{*}$ & 0,02501 & $0,14817^{\star * *}$ & $0,07844^{*}$ \\
\hline$\lambda_{W T I}$ & $0,12394^{* *}$ & $-0,10979$ & $-0,01761$ & $0,09897^{\star * *}$ & $0,16251^{* * *}$ \\
\hline \multicolumn{6}{|c|}{ Conditional Variance Estimates } \\
\hline$\alpha_{0}$ & $0,00002^{* * *}$ & $0,000^{* *}$ & $0,00000^{* * *}$ & $0,00002^{\star * *}$ & $0,00005^{* * *}$ \\
\hline$\alpha_{1}$ & $0,11961^{\star * *}$ & $0,07781^{\star * *}$ & $0,15267^{\star * *}$ & $0,12451^{\star * \star}$ & $0,11991^{* * *}$ \\
\hline$\alpha_{2}$ & $0,83641^{\star * *}$ & $0,90335^{\star * *}$ & $0,82853^{* * *}$ & $0,84728^{\star \star *}$ & $0,79016^{* * *}$ \\
\hline$\gamma \mathrm{BRENT}$ & $-0,01187$ & 0,00353 & $-0,01025$ & 0,00726 & 0,01380 \\
\hline$\gamma \mathrm{WTI}$ & 0,01196 & $-0,00481$ & 0,01180 & $-0,00757$ & $-0,01319$ \\
\hline \multicolumn{6}{|c|}{ LB Q-statistics } \\
\hline $\mathrm{LB}(5)$ & 0,6397 & 2,9898 & 6,1566 & $8,9765^{\star *}$ & 1,8148 \\
\hline $\mathrm{LB}(9)$ & 3,5621 & 6,4087 & 9,5561 & 10,834 & 5,5039 \\
\hline $\mathrm{LB}^{2}(5)$ & $8,4067^{\star *}$ & 4,1352 & 4,2990 & 4,0163 & 2,4517 \\
\hline $\mathrm{LB}^{2}(9)$ & 9,1779 & 8,7634 & 8,4638 & 5,4861 & 10,081 \\
\hline
\end{tabular}

Parentheses include the p-value, ${ }^{*}{ }^{* *}$ and ${ }^{* * *}$ indicate significance at 10,5 and $1 \%$ levels, respectively.

10. Kilian L, Park C. The impact of oil price shocks on the U.S. stock market, International Economic Review. 2009;50(4):12671287. Available from: https://doi.org/10.1111/j.1468-2354. 2009.00568.x.

11. Malik F, Ewing BT. Volatility transmission between oil prices and equity sector returns. International Review of Financial Analysis. 2009;18(3):95-100. Available from: https://doi.org/ 10.1016/j.irfa.2009.03.003.

12. Vo M. Oil and stock market volatility: A multivariate stochastic volatility perspective. Energy Economics. 2011;33(5):956-965. Available from: https://doi.org/10.1016/j.eneco.2011.03.005.

13. Arouri $\mathrm{MEH}$, et al. The volatility spillovers between oil and stock markets in Europe, Energy Economics. 2012;34:611-617. Available from: https://doi.org/10.1016/j.eneco.2011.08.009.

14. Degiannakis S, Filis G, Kizys R. The Effects of Oil Price Shocks on Stock Market Volatility: Evidence from European Data. The Energy Journal. 2014;35:35-36. Available from: https://doi.org/ 10.5547/01956574.35.1.3.
15. Apergis N, Miller SM. Do structural oil-market shocks affect stock prices?, Energy Economy. 2009;31:569-575. Available from: https://doi.org/10.1016/j.eneco.2009.03.001.

16. Gomes M, Chaibi A. Volatility Spillovers Between Oil Prices And Stock Returns: A Focus On Frontier Markets. Journal of Applied Business Research (JABR). 2014;30(2):509-526. Available from: https://doi.org/10.19030/jabr.v30i2.8421.

17. Trinh PTT, Dan VL. The asymmetric impact of the oil price fluctuation on the Vietnamese stock market: employ non-linear autoregressive distributed lag model (ARDL), Journal of Asian Business and Economic Studies. 2018;29(9):36-52.

18. Box GEP, George GM. Time Series Analysis: Forecasting and Control. 1970;.

19. Liu YA, Pan MS. Mean and volatility spillover effects in the US and Pacific-Basin stock markets. Multinational Finance Journal. 1997;1:47-62. Available from: https://doi.org/10.17578/11-3. 


\title{
Tác động của thị trường dầu thô quốc tế đến tỷ suất lợi nhuận của các công ty dầu khí ở các nước cận biên khu vực châu Á
}

\author{
Nguyễn Thị Ngân ${ }^{1,}{ }^{*}$, Hoàng Trung Nghĩa ${ }^{1}$, Trương Huỳnh Thúy $\mathrm{Vi}^{2}$
}

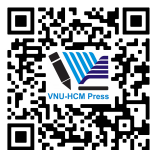

Use your smartphone to scan this QR code and download this article

${ }^{1}$ Trường Đại học Kinh tế - Luật, Đại học Quốc gia TP.HCM, Việt Nam

${ }^{2}$ CTCP Chû́ng khoán SSI, Việt Nam

Liên hệ

Nguyễn Thị Ngân, Trường Đại học Kinh tế Luật, Đại học Quốc gia TP.HCM, Việt Nam

Email: ngannt@uel.edu.vn

Lịch sử

- Ngày nhận: 29-12-2021

- Ngày chấp nhận: 13-5-2021

- Ngày đăng: 18-5-2021

DOI : 10.32508/stdjelm.v5i2.749

\section{Check for updates}

\section{Bản quyền}

๑ ĐHQG Tp.HCM. Đây là bài báo công bố mở được phát hành theo các điều khoản của the Creative Commons Attribution 4.0 International license.

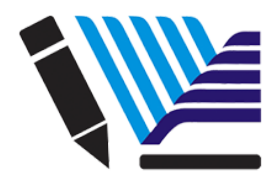

VNU-HCM Press

\section{TÓM TẮT}

Các thị trường cận biên giới khu vực châu Á mang đến cơ hội đầu tư hấp dẫn cho các nhà đầu tư nhằm tìm kiếm lợi nhuận cao hơn và mối tương quan thấp so với các tài sản truyền thống. Việc nghiên cứu cơ chế truyền dẫn sự biến động giữa các thị trường này có vai trò quan trọng trong việc đưa ra quyết định phân bổ danh mục đâu tư. Bài báo xem xét mức độ lan tỏa của tỷ suất lợi nhuận và độ biến động từ thị trường dầu thô quốc tế tác động đến thị trường chứng khoán dầu khí ở các nước cận biên khu vực châu Á. Ứng dụng mô hình ARMA $(1,1)$-GARCH $(1,1)$, bài viết xây dựng mô hình lan truyền trong tỷ suất lợi nhuận và độ biến động nhằm đánh giá tác động của thị trường khu vực (DSE, CSE, HNX, HOSE) và thị trường quốc tế (ICE) đến tỷ suất lợi nhuận của các công ty dầu khí ở Bangladesh, Sri Lanka và Việt Nam. Sử dụng tỷ suất lợi nhuận hàng ngày trong giai đoạn từ 04/01/2010 đến 31/12/2019, bài nghiên cứu cho thấy thị trường dầu Brent và WTI có ảnh hưởng đến thị trường chứng khoán dầu khí ở Việt Nam và Sri Lanka. Tuy nhiên, mức độ ảnh hưởng của WTI đến độ biến động của các công ty ở Sri Lanka không đáng kể. Đối với thị trường Bangladesh, điều đáng chú ý là không tìm thấy tác động lan truyên có ý nghĩa thống kê. Kết quả có thể được giải thích bởi sự khác nhau trong tiến trình cải cách khu vực năng lượng cũng như tầm quan trọng của thị trường dầu ở những quốc gia này. Kết quả nghiên cứu cho thấy các thị trường cận biên, cụ thể là Bangladesh và Sri Lanka có tiềm năng mang đến lợi ích đa dạng hóa bởi mức độ tương quan với các thị trường phát triển thấp. Bài báo góp phần cung cấp thêm thông tin cho các nhà hoạch định chính sách, nhà kinh tế trong việc đánh giá mức độ lan truyền của thị trường dầu thô quốc tế đến thị trường các nước cận biên. Các nhà đầu tư có thể tận dụng lợi thế của chiến lược đa dạng hóa ở những thị trường cận biên trong việc tối đa hóa lợi nhuận đầu tư.

Từ khoá: Lan truyền, tác động độ biến động, hợp đông tương lai dầu thô, tỷ suất lọi nhuận các công ty dâu khí, thị trường cận biển khu vực châu Á
Trích dẫn bài báo này: Ngân N T, Nghĩa $\mathrm{H} \mathrm{T,} \mathrm{Vi} \mathrm{T} \mathrm{H} \mathrm{T.} \mathrm{Tác} \mathrm{động} \mathrm{của} \mathrm{thị} \mathrm{trường} \mathrm{dầu} \mathrm{thô} \mathrm{quốc} \mathrm{tế} \mathrm{đến} \mathrm{tỷ}$ suất lợi nhuận của các công ty dầu khí ở các nước cận biên khu vực châu Á. Sci. Tech. Dev. J. - Eco. Law Manag.; $\dot{5}(2): 1535-1548$. 